\title{
Опыт реконструкции производных березняков в Западно-Хэнтэйской лесорастительной провинции (Монголия)
}

\section{Reconstruction experience of birch derivative plantations in the Western Khentey forest vegetational province (Mongolia)}

\author{
Лобанов А. И. ${ }^{1}$, Булган-Эрдэнэ Б. ${ }^{2}$, Цэдэндаш.$^{3}$, Дугаржав Ч. ${ }^{3}$, Доржсурэн Ч. ${ }^{3}$ \\ Lobanov A. I. ${ }^{1}$, Bulgan-Erdene B. ${ }^{2}$, Tsedendash G. ${ }^{3}$, Dugarjav Ch. ${ }^{3}$, Dorjsuren Ch. ${ }^{3}$ \\ ${ }^{1}$ Научно-исследовательский институт аграрных проблем Хакасии, г. Абакан, Россия. E-mail: anatoly-lobanov@ksc.krasn.ru \\ ${ }^{2}$ Монгольский государственный университет образования, г. Улаанбаатар, Монголия. E-mail: bbulga4421@gmail.com \\ ${ }^{3}$ Институт общей и экспериментальной биологии AHМ, Монголия. E-mail: chdugaa@yahoo.com \\ ${ }^{1}$ Scietific Research Institute of Agrarian Problems of Khakassia, Abakan, Russia \\ ${ }^{2}$ Mongolian State University of Education, Ulaanbaatar, Mongolia \\ ${ }^{3}$ Institute of General and Experimental Biology MAS, Ulaanbaatar, Mongolia
}

Peфepam. Обобщен опыт реконструкции производных березняков коридорным способом методом создания лесных культур хвойных пород в условиях Западно-Хэнтэйской лесорастительной провинции Монголии.

Ключевые слова. Западный Хэнтэй, лесные культуры, Монголия, производный березняк, реконструкция.

Summary. The article shows the experience of birch derivative plantations' reconstruction with the help of corridor method by creating of coniferous forest plantations within the conditions of Mongolia Western Khentey forest province.

Key words. Birch derivative plantation, Mongolia, reconstruction, silviculture, Western Khentey.

\section{Введение}

Площадь лесных экосистем Монголии составляет 17,9 млн. га. Лесопокрытая площадь занимает 12,3 млн. га, из них хвойными и лиственными лесами занято 10,4 млн. га (84,6 \%), саксаулами 1,9 млн. га (15,4 \%), в том числе ерники составляют 0,78 млн. га (6,3 \%) (Доржсурэн, Тунгалаг, 2017). Хвойные и лиственные леса приурочены к горным системам Северной Монголии, развивающимся на южном пределе бореальных лесов Северной Евразии, саксаульники распространены в южной гобийской части страны. Из площади хвойных и лиственных лесов лиственничниками занято 73,8 \%, березняками $-12,3 \%$, кедровниками $-6,4 \%$, сосняками $-5,0 \%$ и остальными древесными породами $-2,4 \%$ (Лобанов и др., 2018).

Возрастающее влияние антропогенных воздействий на леса (рубки, лесные пожары) приводит к нарушению выполняемых ими климаторегулирующих, водоохранных, почвозащитных, санитарно-гигиенических и иных функций, поэтому чрезвычайно актуальными становятся проблемы рационального использования, восстановления, охраны лесов и борьба со сменой древесных пород (Колданов, 1966; Савин, 1978; Леса МНР, 1978, 1980; Доржсурэн, 2009; Лобанов и др., 2015).

Только за последнюю четверть века в Монголии было заготовлено 29,2 млн м² древесины, 8,2 млн га охвачено лесными пожарами и 2,1 млн га повреждено насекомыми-вредителями (Доржсурэн, 2009), что привело к значительной смене древесных пород и ухудшению качественного состава лесов.

Особого внимания заслуживают большие площади производных лиственных древостоев, образовавшихся на месте вырубок и гарей в сосновых, реже в лиственничных древостоях. Перевод значительной части этих насаждений в хвойные следует рассматривать в качестве одного из ведущих направлений исследований на ближайшую перспективу в повышении продуктивности и улучшении качественного состава лесов Монголии (Исаев и др., 1990; Лобанов и др., 2018). 
Реконструкция производных лиственных насаждений уже давно привлекает внимание исследователей (Орленко, 1955; Пухалис, 2000; Чмыр, 2002). В условиях Монголии первые опытные работы по реконструкции производных березняков были начаты нами лишь в 2012 г. (Лобанов и др., 2018).

Цель работы заключается в обобщении опыта реконструкции производных березняков в Западно-Хэнтэйской лесорастительной провинции Монголии.

\section{Материалы и методы}

Экспериментальные исследования проведены на территории Селенгинского аймака в пределах Шарынгольского лугово-лесного стационара Совместной Российско-Монгольской комплексной биологической экспедиции РАН и АНМ. Этот район с восточной стороны граничит с центральной частью Хэнтэйского нагорья, с западной стороны - со степью Монгольской Даурии (Грубов, 1955) и от других районов Монголии отличается своеобразием горного рельефа и широким распространением сезонно-промерзающих почв (Краснощеков, 2013). Он по лесорастительному районированию (Коротков, Цэдэндан, 1983) отнесен к Западно-Хэнтэйской лесорастительной провинции Южно-Забайкальской котловинно-горной области.

Объектом исследований послужил производный березняк, представленный березой плосколистной (Betula platyphylla Sukacz.) с незначительной примесью сосны обыкновенной (Pinus sylvestris L.) и осины (Populus tremula L.), поселившихся здесь после сплошной рубки сосняка и последующих лесных пожаров разной интенсивности. Березняк формируется на дерновых лесных почвах (Коротков, 1978) Для изучения его таксационных особенностей и опытных работ были заложены две постоянные пробные площади (ППП) размером 0,05 и 0,04 га согласно ОСТ (1983). Географические координаты ППП - 49010'44.6" с. ш., 106³9'18.0" в. д. ППП расположены на пологом склоне северной экспозиции крутизной 2-10 на абсолютной высоте 1101-1105 м над ур. м. На ППП методами, принятых в лесной таксации (Анучин, 1982; Методы ..., 2002), по породам и ярусам были обмерены все деревья и кустарники с описанием травянистого покрова и определением его проективного покрытия (Сукачев, Зонн, 1961).

\section{Результаты и их обсуждение}

Анализ полученных материалов показывает, что в условиях Западно-Хэнтэйской лесорастительной провинции на старых сплошных вырубках коренной ценопопуляции сосны обыкновенной формируются производные березняки с незначительной примесью сосны обыкновенной и осины (рис. 1). Они состоят из двух поколений (ярусов) и характеризуются в большинстве случаев невысокой производительностью. Средний класс бонитета III,9, средний запас на 1 га - 53,2 м (березняк осоково-ирисово-разнотравный) и 88,8 м³ (березняк ирисово-осоково-разнотравный) (табл.). Первое поколение пред-

Таблица

Таксационные показатели производных березняков (по: Лобанов, Дугаржав, 2018)

\begin{tabular}{|c|c|c|c|c|c|c|c|c|}
\hline \multirow{2}{*}{ Ярус } & \multirow{2}{*}{ Порода } & \multirow{2}{*}{$\begin{array}{c}\text { Кол-во } \\
\text { деревьев, } \\
\text { эКз./га }\end{array}$} & \multicolumn{2}{|c|}{ Средние } & \multirow{2}{*}{ Состав } & \multirow{2}{*}{ Полнота } & \multirow{2}{*}{$\begin{array}{c}\text { Сумма } \\
\text { площадей } \\
\text { сечения, }{ }^{2} / г а\end{array}$} & \multirow{2}{*}{$\begin{array}{l}\text { Запас, } \\
\text { м/ }^{3}\end{array}$} \\
\hline & & & $\mathrm{H}, \mathrm{M}$ & $\mathrm{D}, \mathrm{cm}$ & & & & \\
\hline \multicolumn{9}{|c|}{ ППП-1. Березняк осоково-ирисово-разнотравный } \\
\hline I & Береза & 120 & 18,1 & 26,8 & \multirow{4}{*}{$\begin{array}{l}75 Б(60) \\
25 \mathrm{Б}(32) \\
+\mathrm{Oc}(20)\end{array}$} & 0,27 & 6,76 & 51,8 \\
\hline \multirow{2}{*}{ II } & Береза & 20 & 8,4 & 12,8 & & 0,06 & 0,26 & 0,8 \\
\hline & Осина & 20 & 10,3 & 9,0 & & 0,03 & 0,13 & 0,6 \\
\hline \multicolumn{2}{|c|}{ ИТОГО } & 160 & & & & 0,36 & 7,14 & 53,2 \\
\hline \multicolumn{9}{|c|}{ ППП-2. Березняк ирисово-осоково-разнотравный } \\
\hline I & Береза & 100 & 19,6 & 32,0 & \multirow{4}{*}{$\begin{array}{c}64 \mathrm{Б} \\
(80-90) \\
22 \mathrm{C} 14 \mathrm{Б} \\
(25-50)\end{array}$} & 0,32 & 8,03 & 63,75 \\
\hline II & Сосна & 175 & 12,2 & 14,2 & & 0,10 & 2,79 & 17,05 \\
\hline II & Береза & 250 & 9,1 & 9,4 & & 0,12 & 1,73 & 8,00 \\
\hline \multicolumn{2}{|c|}{ ИТОГО } & 525 & & & & 0,53 & 12,54 & 88,8 \\
\hline
\end{tabular}




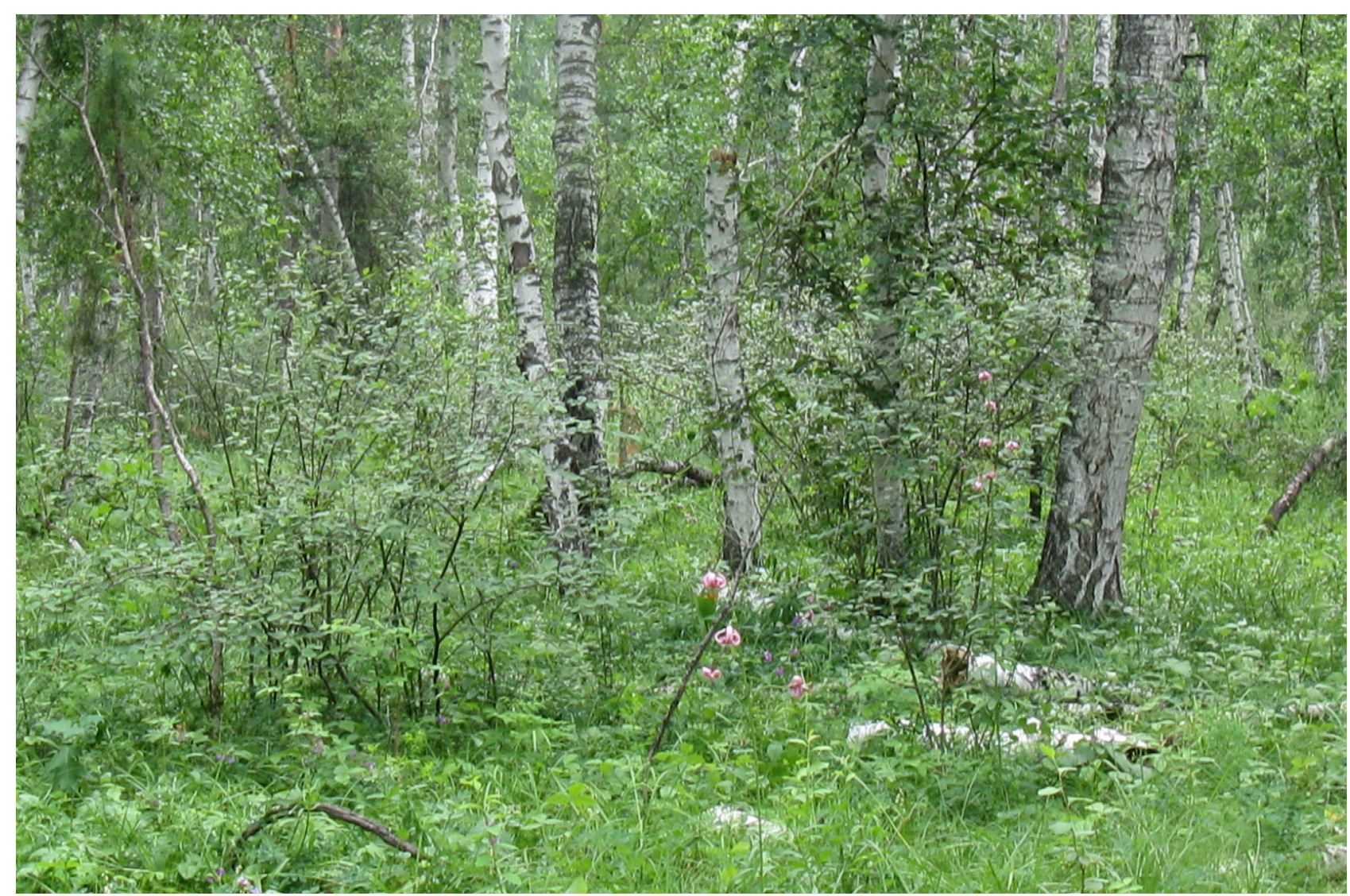

Рис. 1. Общий вид производного березняка до его реконструкции.

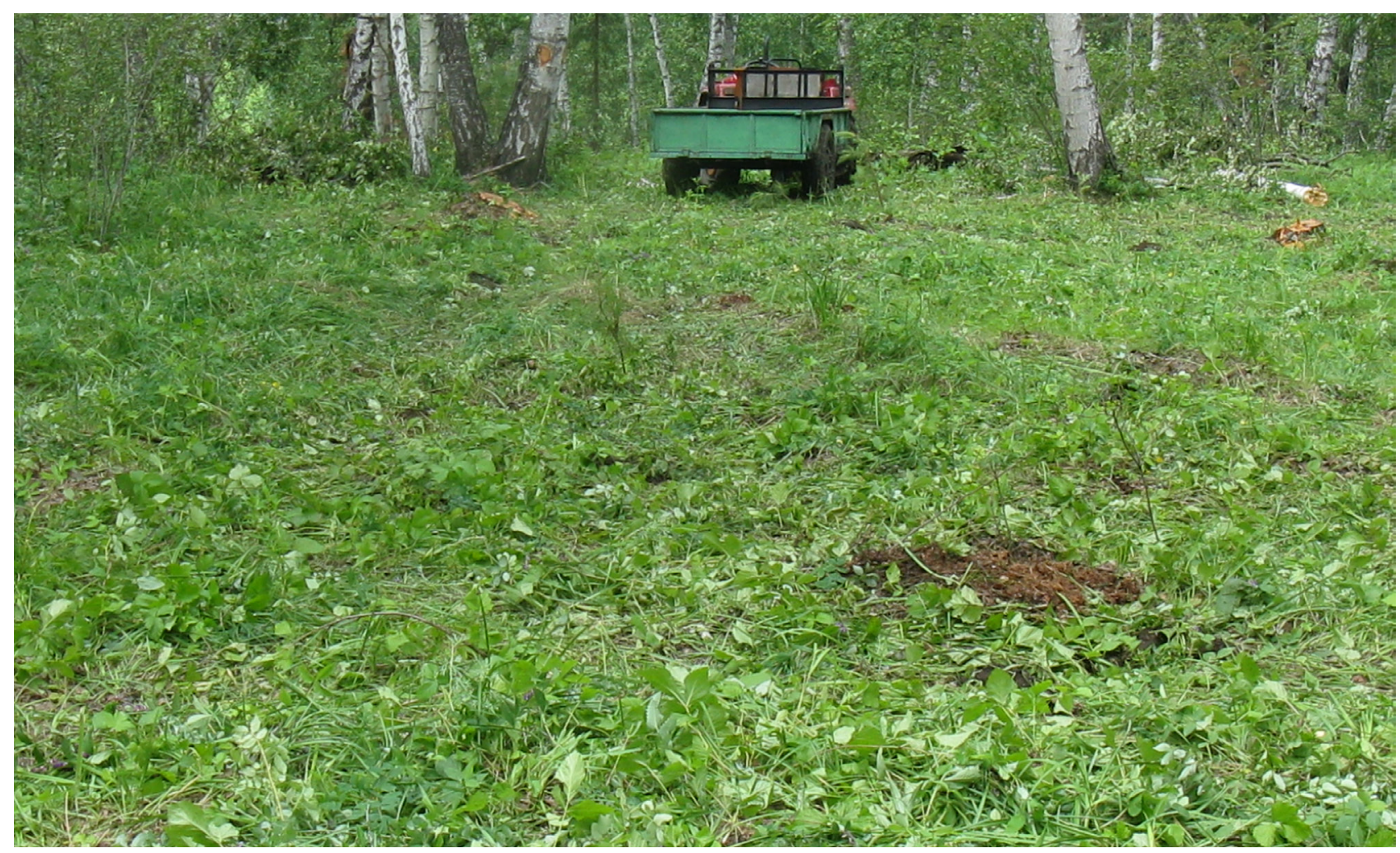

Рис. 2. Общий вид коридорных пространств шириной 10 м, образованных реконструктивной рубкой. 


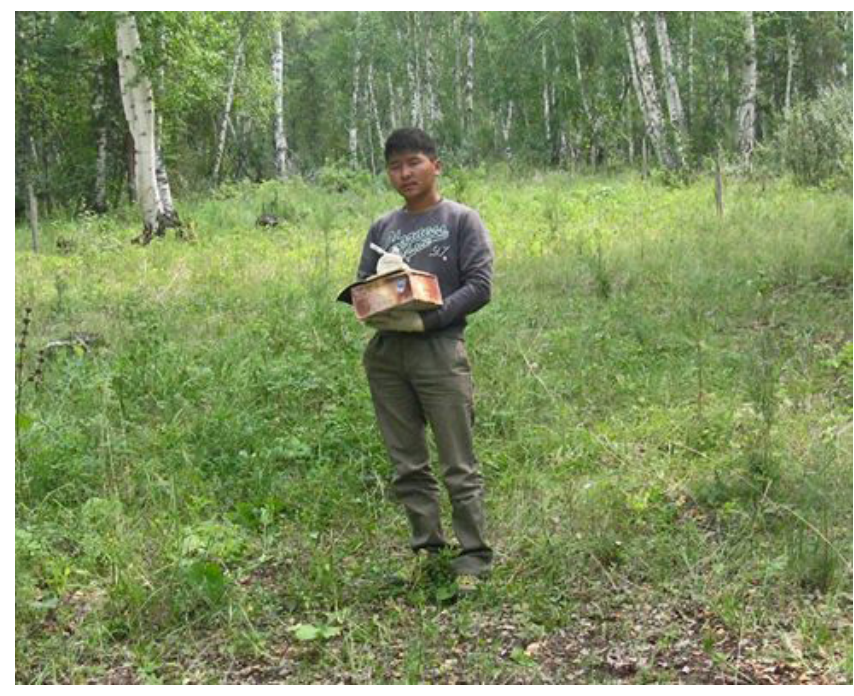

Рис. 3. Общий вид реконструированного березняка методом создания культур сосны обыкновенной. ставлено деревьями березы 60-90-летнего возраста. Средняя высота их варьирует от 18,1 до 19,6 м при среднем диаметре от 26,8 до 32,0 см. Возраст у второго поколения березы колеблется от 25 до 50 лет. Средняя высота деревьев варьирует от 8,4 до 9,1 м при среднем диаметре от 9,4 до 12,8 см.

Подрост сосны обыкновенной здесь отсутствует. В подлеске в 2012 г. встречались кизильник черноплодный (Cotoneaster melanocarpa Lodd.), шиповник иглистый (Rosa acicularis Lindl.), спирея средняя (Spiraea media F. Schmidt.). В травянистом покрове с общим проективным покрытием 85 \% насчитывалось 36 видов растений. Среди них преобладали: осока амгунская (Carex amgunensis Fr. Schmidt.), ирис русский (Iris ruthenica Ker-Gawl.), костяника каменистая (Rubus saxatilis L.), клубника восточная (Fragaria orientalis Losinsk.), осока стоповидная (Carex pediformis C. А. Меу), мятлик сибирский (Poa sibirica L.), чина приземистая (Lathyrus humilis (Ser.) Spreng.), горошек байкальский (Vicia baicalensis (Turcz.) B. Fedtsch.). Сырая масса травянистых растений варьировала здесь от 353 до 366 г/м². Хорошо развитая трявянистая растительность служила мощным фактором, препятствующим искусственному лесовосстановлению.

Данный производный березняк по своему составу и продуктивности не соответствовал лесорастительным условиям участка и целевому назначению. В связи с этим в 2012 г. нами впервые в Монголии были проведены сплошные реконструктивные рубки и удалены все деревья и кустарники на ограниченных площадях специально проложенных коридоров шириной 10 м (рис. 2) на двух участках, имеющих первый участок С-Ю направление, второй - 3-В направление. Для борьбы с пневой порослью и травянистой растительностью в этот же год применили сплошным опрыскиванием химический гербицид (арборицид) «Торнадо» из расчета 160 г действующего вещества на 10 литров воды. Эта мера позволила на следующий год полностью отказаться от агротехнических уходов. Весной 2013 г. на 75 \% площади коридорных пространств методом посадки по схеме посадки 2,5 × 1,0 м были заложены культуры сосны обыкновенной и на 25 \% площади - культуры лиственницы сибирской (рис. 3). Сохранность культур хвойных пород в год посадки составляла 100 \%.

В процессе роста и развития через 5 лет после посадки около 20 \% из числа высаженных экземпляров сосны обыкновенной в разные годы зимних периодов были повреждены косулями. В 2018 г. нами было произведено дополнение культур в размере 20 \% от первоначально высаженных растений. В посадках лиственницы сибирской повреждений косулями не было обнаружено.

\section{Заключение}

Реконструкция производных березняков в Западно-Хэнтэйской лесорастительной провинции Монголии позволила в более короткие сроки, по сравнению с естественным процессом, получить смешанные насаждения с заданным участием хозяйственно-ценных хвойных древесных пород. Ранее начатые работы по реконструкции малоценных насаждений в лесах Монголии следует продолжить и провести их в более молодых (до 5 лет) лиственных древостоях.

\section{ЛИТЕРАТУРА}

Анучин Н. П. Лесная таксация. Изд. 5-е. - М.: Лесн. пром-сть, 1982. - 550 с.

Грубов В. И. Конспект флоры Монгольской Народной Республики // Тр. Монгольской экспедиции. - М.-Л.: Изд-во АН СССР, 1955. - Вып. 67. - 307 с. 
Доржссурэн Ч. Антропогенные сукцессии в лиственничных лесах Монголии. - М., 2009. - 260 с. (Тр. Совместной Российско-Монгольской комплексной биологической экспедиции; Т. 50).

Доржссурэн Ч., Тунгалаг М. Глава III. Состояние и изменение лесов Монголии // Природа Монголии. Том III. Биологические разнообразия Монголии. - Улан-Батор: Мунхин Усэг, 2017. - С. 221-246 (на монг. яз.).

Исаев А. С., Петренко Е. С., Савин Е. Н., Краснощеков Ю. Н., Коротков И. А., Дугаржав Ч. Особенности функционирования и проблемы рационального использования лесных экосистем на южной границе лесов Евразии // Экология и природопользование в Монголии: тез. докл. междун. конф. (4-6 сентября 1990 г., г. УланБатор) - Улан-Батор, 1990. - С. 15-17.

Колданов В. Я. Смена пород и лесовосстановление. - М.: Лесн. пром-сть, 1966. - 171 с.

Коротков И. А. Закономерности распределения лесов в Монгольской Народной Республике // Леса Монгольской Народной Республики (география и типология) / Отв. ред. А. Б. Жуков. - М.: Наука, 1978. - С. $36-46$.

Коротков И. А., Цэдэндаш Г. Карта лесов Монгольской Народной Республики (М. 1:1500000). -М.: ГУГК МНР и ГУГК СССР, 1983 (врезка).

Краснощеков Ю. Н. Структура почвенного покрова горных лесов Хэнтэйского нагорья в Монголии // Вестник КрасГАУ, 2013. - № 12. - С. 77-82.

Леса Монгольской Народной Республики (география и типология) /Отв. ред. А. Б. Жуков. - М.: Наука, 1978. $-127 \mathrm{c}$.

Леса Монгольской Народной Республики (хозяйственное использование) / Отв. ред. А. Б. Жуков, Е. Н. Савин. М.: Наука, 1980. - 148 с.

Лобанов А. И., Савин Е. Н., Краснощеков Ю. Н., Ярмишко В. Т., Ярмишко М. А., Дугаржав Ч., Доржссурэн Ч., Цэдэндаш Г., Цогт 3., Дашзэвэг Ц., Гэрэлбаатар С. Приемы восстановления хвойных пород после антропогенных воздействий в лесах Монголии // Экосистемы Центральной Азии в современных условиях социально-экономического развития: мат-лы междун. конф. (8-11,сентября 2015 г., Улан-Батор (Монголия)). Улан-Батор, 2015. - Т. 2. - С. 231-235.

Лобанов А. И., Дугаржав Ч. Таксационные показатели производных березняков Западного Хэнтэя Монголии // Наука сегодня: проблемы и пути решения: мат-лы междун. научно-практич. конф. (28 марта 2018 г., г. Вологда). - Вологда: ООО «Маркер», 2018. - Ч. 1. - С. 115-117.

Лобанов А. И., Булган-Эрдэнэ Б., Цэдэндаш Г., Доржсурэн Ч., Дугаржнав Ч., Гэрэлбаатар С., Хадбаатар С. Опыт улучшения качественного состава лесов Монголии // Наука сегодня: теоретические и практические аспекты: мат-лы междун. научно-напрктич. конф. (, 26 декабря 2018 г., г. Вологда). - Вологда: ООО «Маркер», 2018. C. $15-17$.

Методы изучения лесных сообществ / Е. Н. Андреева, И. Ю. Бакал, В. В. Горшков [и др.]. - СПб.: НИИХимии СПб ГУ, 2002. - 240 с.

Орленко Е. Г. О реконструкции лиственных молодняков // Лесное хозяйство, 1955. - № 9. - С. 14.

OCT 56-69-83. Площади пробные лесоустроительные. Метод закладки. - М., 1983. - 60 с.

Пухалис $\boldsymbol{A}$. $\boldsymbol{A}$. К вопросу о необходимости разработки методов реконструкции малоценных насаждений // Непрерывное экологическое образование и экологические проблемы Красноярского края: мат-лы 5-ой юбилейной регион. конф. (25 апреля 2000 г., г. Красноярск). - Красноярск: СибГТУ, 2000. - С. 241-242.

Савин $\boldsymbol{E}$. $\boldsymbol{H}$. Краткие итоги изучения лесов МНР // Лесные богатства Монголии и их использование. - Улан-Батор, 1978. - С. 56-62.

Сукачев В. Н.,Зонн С. В. Методические указания к изучению типов леса. - М.: Изд-во АН СССР, 1961. - 144 с.

Чмыр $\boldsymbol{A}$. Ф. Структура и экология вторичных лиственных лесов и их реконструкция. - СПб.: СПбНИИЛХ, 2002. -234 c. 